Prismatika: Jurnal Pendidikan dan Riset Matematika Vol. 3 No. 1 (2020)

p-ISSN: 2654-6140, e-ISSN: 2656-4181

http://ejurnal.budiutomomalang.ac.id/index.php/prismatika

\title{
IDENTIFIKASI PROSES BERPIKIR KONSEPTUAL SISWA SMP MELALUI METODE MIND MAPPING
}

\author{
Dwi Noviani Sulisawati' ${ }^{1}$ Eric Dwi Putra ${ }^{2}$ \\ IKIP PGRI Jember ${ }^{1,2}$ \\ dwi.moshimoshi@gmail.com¹, dwieric454@gmail.com²
}

\begin{abstract}
Abstrak
Pentingnya penekanan pemahaman materi, kreativitas, kebebasan berekspresi dan pemahaman guru tentang proses berpikir siswanya maka dengan adanya penelitian ini, peneliti ingin memberikan gambaran proses berpikir siswa SMP melalui metode mind mapping yang dilakukan kepada tiga subjek dengan kemampuan matematika yang berbeda. Subjek dipilih secara purposive sampling sesuai dengan kriteria yang telah ditentukan. Pengambilan data dilakukan menggunakan metode tes berupa pemberian tugas membuat peta konsep tentang materi yang sedang diajarkan guru dan wawancara seputar hasil pekerjaan mereka. Selanjutnya data diolah menggunakan analisis data kualitatif yang meliputi reduksi, penyajian data dan penarikan kesimpulan. Berdasarkan hasil analisis didapatkan bahwa siswa dengan kemampuan tinggi dapat memenuhi 8 dari 9 indikator yang ada. Siswa dengan kemampuan sedang mampu memenuhi 7 dari 9 indikator yang diajukan sedangkan pada siswa dengan kemampuan rendah hanya mampu memenuhi 6 dari 9 indikator yang ada. Tetapi dalam hal penggunaan warna, siswa dengan kemampuan rendah justru mampu menggunakan lebih banyak variasi warna dengan teknik gradasi. Diharapkan ke depannya penelitian ini bisa mengambil subjek lain dengan berbagai variabel yang mampu menunjang proses berpikir siswa.
\end{abstract}

Kata kunci: proses berpikir, konseptual, mind mapping

\begin{abstract}
The importance of emphasizing material understanding, creativity, freedom of expression, and teachers 'understanding of the thinking processes of their students, so with this research, the researcher wants to provide an overview of junior high school students' thinking processes through the mind mapping method which is carried out on 3 subjects with different mathematical abilities. Subjects were selected by purposive sampling according to predetermined criteria. The data was collected using the test method in the form of giving the task of making concept maps about the material being taught by the teacher and interviews about the results of their work. Furthermore, the data was processed using qualitative data analysis which includes reduction, data presentation, and drawing conclusions. From the analysis, it was found that students with high abilities could fulfill 8 of the 9
\end{abstract}


indicators. For students with moderate ability, they can meet 7 of the 9 indicators proposed, while students with low abilities were only able to meet 6 of the 9 indicators. But in terms of using colors, students with low abilities were able to use more color variations with gradation techniques. Further research can take other subjects with various variables that are able to support students' thinking processes.

Keywords: thinking process, conceptual, mind mapping

\section{PENDAHULUAN}

Artikel ini merupakan salah satu bentuk publikasi hasil penelitian kami yang dilakukan untuk mengetahui efektivitas penggunaan model belajar mind mapping dalam meningkatkan hasil belajar siswa SMP. Sebagai efek dari temuan lain pada penelitian kami, artikel ini lebih lanjut akan menggambarkan tentang proses berpikir siswa SMP melalui metode mind mapping yang dilakukan kepada tiga subjek dengan kemampuan matematika yang berbeda. Kenyataan di lapangan menunjukkan bahwa tingkat pemahaman siswa terhadap materi yang sedang diajarkan oleh guru masih tergolong sangat rendah. Hal ini dapat dilihat melalui data nilai ulangan matematika di kelas VII SMP Terbuka Negeri 1 Gumukmas Jember yang menunjukkan bahwa nilai yang diperoleh siswa masih banyak yang berada di bawah standar Kriteria Ketuntasan Minimal (KKM) yang telah ditetapkan. Dimana ditemukan 80\% siswa memiliki nilai di bawah standar KKM. Selain itu, ditemukan juga bahwa masih banyak siswa kelas VIII mencatat dan merasa bosan dengan proses pembelajaran Matematika. Sebagian siswa mengeluhkan jika seringkali kesulitan dalam menyesaikan permasalahan yang diberikan guru jika permasalahan tersebut berbeda dengan apa yang sudah dicontohkan oleh gurunya. Beberapa siswa juga terlihat lebih senang mengerjakan kegiatan lain di luar kegiatan pembelajaran yang seharusnya, misalnya bercanda dengan teman sebangkunya, mengganggu teman sekelasnya, bernyanyi ataupun bergumam sendiri.

Hasil wawancara yang telah dilakukan terhadap Guru Bidang Studi Matematika yang mengajar di kelas tersebut juga mengungkapkan bahwa sebagian besar permasalahan yang muncul di kelas tersebut disebabkan masih berpusatnya pembelajaran hanya kepada guru dan sebagian besar siswa hanya mengandalkan gurunya sebagai sumber informasi dan materi ajar yang harus mereka kuasai. Di sisi lain, selama kegiatan belajar mengajar sedang berlangsung, guru jarang mengkombinasikan ataupun menggunakan model, pendekatan, metode serta sumber belajar yang bervariasi.

Setelah mengetahui karakteristik berpikir siswa, untuk mengetahui proses berpikir konseptual siswa dapat dilakukan dengan penyampaian 
pembelajaran menggunakan metode yang berbeda jika dibandingan dengan metode yang selama ini digunakan guru adalah menjadi dua hal yang sangat penting sebagai langkah awal memperbaiki permasalahan-permasalahan yang muncul. Sehingga dengan begitu akan membantu kita sebagai guru untuk memilih kegiatan pembelajaran yang sesuai dengan kecenderungan proses berpikir yang dimiliki oleh siswa-siswa tersebut.

Melalui kolaborasi yang cantik maka anggapan bahwa matematika adalah salah satu mata pelaaran yang sulit, membosankan, dan tidak menarik sejatinya bisa ditepis karena dalam matematika justru terkandung pembelajaran dan pembiasaan tentang bagaimana cara seseorang untuk belajar berpikir dan bernalar, dimana kegiatan ini sangat bermanfaat dalam proses kerja otaknya, terutama pada saat siswa belajar untuk memecakan masalah (Masfingatin, 2014).

Selama proses pemecahan masalah berlangsung itulah yang sangat memerlukan pemikiran yang ketat. "Berpikir sendiri adalah kemampuan jiwa untuk meletakkan hubungan antara bagian-bagian pengetahuan. Ketika berpikir dilakukan, maka disanalah terjadi proses" (Djamarah, 2008). Berpikir adalah suatu istilah yang memiliki berbagai definisi yang luas, seperti bentuk pertimbangan, angan-angan, pemecahan masalah, perencanaan, penentuan dan kreativitas (Harriman dalam Maulidya, 2018). Sedangkan proses berpikir adalah serangkaian langkah yang digunakan seseorang ketika mereka menerima, mengolah, dan memanggil kembali informasi dari dalam ingatannya yang akan disesuaikan dengan skema yang telah tersimpan di dalam otaknya (Suparni, 2000). Marpaung (1986) juga menyatakan bahwa proses berpikir adalah suatu urutan kegiatan yang terdiri dari penerimaan informasi (dari luar atau dari dalam diri siswa), pengolahan, penyimpulan, dan pemanggilan kembali informasi tersebut dari ingatan yang dimiliki oleh siswa. Selanjutnya Suryabrata (2006) lebih lanjut menjelaskan bahwa suatu jalan atau proses berpikir mempunyai tiga langkah yaitu (1) pembentukan pengertian yang terdiri dari menganalisis, membandingbandingkan, mengabstraksikan dengan menyisihkan, membuang dan menangkap ciri-ciri yang hakiki; (2) pembentukan pendapat dan (3) penarikan kesimpulan.

Proses berpikir sejatinya menunjukkan serangkaian tahapan yang dimiliki seseorang ketika menerima informasi yang diberikan yang kemudian akan diolah untuk merumuskan sebuah kesimpulan dan nantinya akan disimpan oleh memori yang akan mampu dipanggil kembali ketika menyelesaikan permasalahan terutama yang terkait dengan pemecahan masalah (Susandi \& Widyawati, 2017; Choirudin 2015). Lebih detail Zuhri dalam Yanti \& Syazali (2016)menyebutkan bahwa proses berpikir berdasarkan penyelesaian terhadap permasalahan dapat digolongkan 
menjadi tiga bagian yaitu proses berpikir konseptual, proses berpikir semi konseptual dan proses berpikir komputasional. Proses berpikir konseptual merupakan cara berpikir seseorang yang selalu menyelesaikan soal dengan menggunakan konsep yang telah dimiliki berdasarkan hasil pengolahan informasinya selama ini, sedangkan proses berpikir semi konseptual adalah proses berpikir yang cenderung menggunakan konsep dalam menyelesaikan permasalahan yang dialami tetapi kemungkinan dikarenakan kurang lengkapnya pemahaman yang dimilikinya sehingga proses penyelesaiannya dicampur dengan cara penyelesaian yang menggunakan intuisi (Retna, Mubarokah, \& Suhartatik, 2013; Prasetyo, 2015). Serta proses berpikir komputasional merupakan proses berpikir yang biasanya tidak menggunakan konsep tetapi lebih mengandalkan intuisinya dalam menyelesaikan permasalahan (M.S Anwar, 2015)

Berpikir konseptual didefinisikan sebagai kemampuan dalam mengidentifikasi pola atau hubungan yang tidak tampak dengan jelas. Termasuk juga pada bagiannya adalah kemampuan untuk membuat suatu kesimpulan dari berbagai informasi yang ada dimana kemungkinan informasi-informasi tersebut tidak lengkap hingga menjadi sesuatu yang jelas, mengidentifikasi kunci atau dasar permasalahan di dalam situasi yang kompleks dan menciptakan konsep-konsep baru (Indosdm dalamHamda, 2020). Menurut Hiebert dan Lefevre, (Zubaidah, 2000) berpikir konseptual adalah serangkaian kegiatan berpikir menggunakan fakta dan konsep yang saling terkait satu dengan yang lainnya.

Kemampuan berpikir konseptual menjadi sangat penting untuk seseorang dan akan berguna ketika mereka menghadapi masalah. Berpikir konseptual dapat memberikan kekuatan yang besar bagi individu untuk dapat melakukan penyesuaian diri dengan lingkungan sekitarnya sehingga membuat lingkungan menjadi suatu bagian dari diri kita (Skemp, 1987). Hal ini juga berkaitan dengan penggunaan simbol-simbol untuk menyatakan suatu ide/gagasan. Semakin tinggi konsep yang diwakili oleh suatu simbol, maka akan semakin banyak pengalaman yang terkandung di dalamnya. Pebelajar konseptual diyakini bisa menguasai berbagai item konsep, sebab mereka memiliki kemampuan dalam menyelidiki suatu informasi yang diperoleh dan menjelaskan alasan yang menjadi dasar proses pengamatan dan penarikan kesimpulan mereka tentang suatu fenomena ilmiah. Sedangkan kemampuan konseptual matematis biasanya merupakan suatu usaha dalam upaya menumbuhkan pemahaman siswa terhadap beberapa konsep matematika yang berbeda, dan mengurangi penggunaan hafalan rumus-rumus dan prosedur (Santa dalam Hamda, 2020).

Beberapa literatur menyatakan bahwa penggunaan metode mind mapping seringkali dikatakan sebagai metode yang efektif bagi guru atau 
pengajar yang lain untuk mengajarkan suatu teori atau memberitahukan pengetahuan baru kepada siswa. Dalam mengajarkan siswa untuk mampu berpikir konseptual, metode mind mapping juga dirasa adalah salah satu cara yang efektif yang dapat digunakan untuk mempermudah siswa dalam menerima, mengolah, membuat kesimpulan hingga mampu disimpan dengan baik dalam memori otak daripada menggunakan teknik pencatatan secara konvensional. Menurut Buzan (2008) mind map merupakan cara paling mudah untuk menempatkan informasi yang diinginkan ke dalam otak serta mengambil kembali informasi tersebut ke luar. Selanjutnya, Buzan menyebutkan bahwa mind map adalah cara mencatat yang efektif, kreatif dan secara harfiah dapat "memetakan" pikiran-pikiran. Sedangkan mind mapping adalah cara mencatat yang akan membantu siswa untuk mengkonstruksi pengetahuan yang diterimanya secara padat, ringkas dan jelas dalam membuat tafsiran yang berupa pengkategorian fakta- fakta, pencarian hubungan dan perbedaan, serta penarikan kesimpulan dengan menggunakan simbol, gambar, garis dan warna yang beraneka ragam yang dapat merangsang otak sehingga lebih mudah dipelajari, dibaca, dan diingat oleh siswa (Susanto, 2011).

Tabel 1. Perbedaan Catatan Biasa dengan Mind Mapping

\begin{tabular}{ll}
\hline \multicolumn{1}{c}{ Catatan Biasa } & \multicolumn{1}{c}{ Mind Mapping } \\
\hline Hanya berupa tulisan saja & Berupa simbol, gambar, dan tulisan \\
\hline Menggunakan satu warna & $\begin{array}{l}\text { Menggunakan variasi warna } \\
\text { (berwarna) }\end{array}$ \\
\hline $\begin{array}{l}\text { Butuh waktu lama untuk } \\
\text { mereview ulang catatan }\end{array}$ & $\begin{array}{l}\text { Hanya butuh waktu yang singkat } \\
\text { untuk melakukan review ulang }\end{array}$ \\
\hline Membutuhkan waktu yang & $\begin{array}{l}\text { Waktu yang diperlukan untuk } \\
\text { lebih lama untuk belajar }\end{array}$ \\
\hline belajar lebih cepat dan efektif \\
\hline
\end{tabular}

Berdasarkan uraian tersebut dapat disimpulkan bahwa mind mapping adalah cara mencatat yang kreatif, efektif dan cara termudah untuk menempatkan informasi ke dalam otak dan mengambil informasi ke luar dari otak dengan menggunakan simbol, garis lengkung, dan gambar yang merangsang secara visual dibandingkan cara mencatat tradisional (biasa) yang cenderung satu warna dan kaku. Mind mapping juga digunakan untuk mengembangkan dan memudahkan potensi kerja otak, keterlibatan otak kanan dan otak kiri yang saling bekerjasama akan memudahkan seseorang mengatur dan mengingat segala bentuk informasi baik secara verbal maupun secara tertulis 
Proses penggabungan antara penggunaan metode mind mapping dan usaha guru untuk melakukan analisis tentang proses berpikir konseptual siswa di kelas dalam penelitian ini, diharapkan dapat meningkatkan tingkat pemahaman siswa serta dapat membantu siswa agar lebih mudah dalam menerima, mengolah dan menggunakan kembali memorinya tentang informasi yang sedang mereka butuhkan saat proses penyelesaian masalah. Marpaung (Zubaidah, 2000) memberikan beberapa ciri khusus proses berpikir siswa sebagai berikut: (a) Saat awal proses penyelesaian, siswa mencoba merumuskan kembali soal yang diberikan menggunakan kalimatnya sendiri. (b) Memecahkan soal menjadi beberapa bagian, kemudian mencari hubungan antar bagian-bagian yang terpisah tersebut. (c) Cenderung memulai pemecahan masalah jika sudah mendapatkan ide yang tepat. (d) Jika penyelesaian sementara yang dimiliki salah, maka soal akan diuraikan kembali berdasarkan struktur yang lebih sederhana. (e) Masalah akan dipandang memiliki hubungan dengan masalah yang lain. (f) Masalah yang dihadapi lebih banyak diolah secara mental selama proses berpikir daripada diungkapkan dengan tindakan. (g) Selalu menggunakan konsep dalam penyelesaian masalah. (h) Mampu menyelesaikan langkah-langkah penyelesaian masalah yang telah dilakukan.

Hasil penelitian ini akan menguraikan tentang hasil analisis proses berpikir konseptual siswa pada penggunaan metode mind mapping. Selanjutnya, dalam kegiatan analisis pada penelitian ini, peneliti akan mendeskripsikan hasil analisis berupa karakteristik khusus yang dimiliki siswa yang mengarah kepada tingkat meta-strategi konseptual yang diajukan oleh Hejny, Jirotkova, \& Kratochvilova (2006) yaitu (1) siswa membuat gambaran (image) dalam pikirannya tentang ide yang akan dituangkan secara keseluruhan, (2) siswa melakukan analisis untuk menemukan struktur inti permasalahan, (3) siswa menemukan elemen kunci atau hubungan yang terkandung dalam situasi tersebut, menyangkut pengetahuan tentang keterkaitan unsur-unsur yang diberikan serta yang belum diketahui, (4) siswa membangun suatu strategi penyelesaian setelah elemen kunci atau hubungan kunci ditemukan, serta (5) proses-proses tersebut mengarahkan siswa untuk mencapai tingkatan yang lebih tinggi pada pemahaman permasalahan yang telah dihadapi.

\section{METODE PENELITIAN}

Penelitian ini menggunakan jenis penelitian deskriptif kualitatif yang hasil dari prosedur penelitiannya berupa data deskriptif berupa kata-kata yang berasal dari sumber tertulis ataupun secara lisan dari orang-orang terkait maupun suatu perilaku yang sedang diamati (Bodgam dan Taylor dalam Wahyuniar \& Widyawati, 2017). Penelitian ini disebut penelitian 
deskriptif sebab penelitian ini akan menggambarkan bagaimana proses berpikir konseptual siswa SMP dengan ketika menggunakan metode mind mapping. Nantinya data yang dikumpulkan untuk selanjutnya dilakukan analisis adalah data tentanng hasil pekerjaan siswa dalam membuat peta konsep (mind map) sesuai dengan pemikiran yang mereka miliki, baik secara tertulis ataupun dari hasil wawancara yang dilakukan peneliti kepada subjek penelitian setelah mereka mengerjakan materi yang diberikan.

Subjek dalam penelitian ini sebanyak 16 siswa yang terdiri dari 4 siswa laki-laki dan 12 siswa perempuan yang keseluruhannya merupakan siswa kelas VIII SMP Terbuka Negeri 1 Gumukmas, Jember. Dari ke-16 siswa tersebut, subjek dipilih secara purposive sampling sesuai dengan kriteria yang telah ditentukan dengan langkah awal melakukan pengelompokkan siswa ke dalam tiga kategori yaitu siswa dengan kemampuan tinggi, siswa dengan kemampuan sedang dan siswa dengan kemampuan rendah. Adapun pertimbangan lain bagi peneliti dalam memilih subjek penelitian adalah memastikan bahwa guru yang mengajar di kelas tersebut belum pernah menggunakan metode mind mapping selama proses pembelajaran di kelas. Hal ini dilakukan agar siswa tetap merasa bahwa sedang menemukan permasalahan yang baru saat mereka diminta untuk membuat mind map yang sesuai dengan pemikiran hasil pemikiran mereka sendiri.

Metode pengumpulan data yang digunakan dalam penelitian ini meliputi metode tes berupa pemberian tugas membuat peta konsep tentang materi yang sedang diajarkan guru dan wawancara seputar hasil pekerjaan mereka. Tugas berupa tugas pemecahan masalah yang berisikan instruksi untuk membuat mind map tentang materi yang telah diajarkan. Tugas tersebut diberikan sebanyak 2 kali yang masing -masing diberikan setelah siswa mengikuti proses pembelajaran di kelas. Selanjutnya, wawancara dilakukan kepada siswa sesaat setelah pelaksanaan pembelajaran selesai dan setelah siswa menyelesaikan tugas yang diberikan. Untuk keperluan pengecekan keabsahan data penelitian, peneliti menggunakan metode triangulasi waktu dengan pemberian 2 kali tes.

\section{HASIL DAN PEMBAHASAN}

Langkah awal yang akan dilakukan pada tahap pelaksanaan adalah dengan mengelompokkan siswa ke dalam tiga kelompok yang berbeda, yang meliputi siswa dengan kemampuan tinggi, siswa dengan kemampuan sedang dan siswa dengan kemampuan rendah. Disamping dengan menggunakan tes kemampuan matematika siswa, peneliti juga meminta pertimbangan guru matematika yang mengajar di kelas tersebut guna menentukan subjek penelitian yang benar-benar sesuai dengan kemampuan matematikanya sehari-hari serta mampu berkomunikasi dengan baik. 
Hasil identifikasi proses berpikir konseptual bagi siswa dengan kemampuan tinggi yang didapatkan dari analisis hasil pengerjaan tugas tertulis dan wawancara kepada subjek berkemampuan tinggi dapat dilihat pada tabel di bawah ini.

Tabel 2. Hasil Identifikasi Proses Berpikir Konseptual Melalui Mind Map Siswa Berkemampuan Tinggi

\begin{tabular}{lcc}
\hline \multicolumn{1}{c}{ Indikator } & Tugas I & $\begin{array}{c}\text { Tugas } \\
\text { II }\end{array}$ \\
\hline $\begin{array}{l}\text { Membuat gambaran (image) dalam pikirannya } \\
\text { tentang ide yang akan dituangkan secara keseluruhan }\end{array}$ & $\sqrt{ }$ & $\sqrt{ }$ \\
\hline $\begin{array}{l}\text { Melakukan analisis untuk menemukan struktur inti } \\
\text { permasalahan }\end{array}$ & $\sqrt{ }$ & $\sqrt{ }$ \\
\hline Menemukan elemen kunci atau hubungan & $\sqrt{ }$ & $\sqrt{ }$ \\
\hline Membangun suatu strategi penyelesaian & $\sqrt{ }$ & $\sqrt{ }$ \\
\hline $\begin{array}{l}\text { Siswa mencapai tingkatan yang lebih tinggi pada } \\
\text { pemahaman permasalahan yang telah dihadapi. }\end{array}$ & $\sqrt{ }$ & $\sqrt{ }$ \\
\hline Menggunakan bahasa sendiri & - & - \\
\hline Menggunakan variasi warna (lebih dari 3) & $\sqrt{ }$ & $\sqrt{ }$ \\
\hline Tampilan menarik, jelas dan mudah dipahami & $\sqrt{ }$ & $\sqrt{ }$ \\
\hline Kelengkapan informasi yang disampaikan & $\sqrt{ }$ & $\sqrt{ }$ \\
\hline
\end{tabular}

Berdasarkan tabel 2 di atas, dapat diketahui bahwa subjek dengan kemampuan tinggi dapat memenuhi 8 indikator proses berpikir konseptual dengan membuat gambaran (image) terlebih dahulu dalam pikirannya sebelum melakukan analisis untuk menemukan struktur inti dan elemen kunci untuk berpikir serta membuat suatu strategi pemecahan masalah. Siswa dengan kemampuan tinggi nantinya juga akan berhasil mencapai tingkatan yang lebih tinggi pada pemahaman permasalahan yang dihadapinya. Tetapi sayangnya, pada hasil tertulis pengerjaan tugas siswa dengan kemampuan tinggi, penulis masih mendapati bahwa subjek belum mampu mengungkapkan ide/pemikirannya dengan menggunakan bahasa mereka sendiri. Siswa masih memindahkan bahasa yang ada di buku ke dalam mind map miliknya. Berkenaan tentang penggunaan variasi warna pada tampilan mind map, siswa pada kategori ini mampu memadu padankan warna dengan bagus dan tidak berlebihan, tampilan mind map yang dihasilkan juga rapi, tidak membosankan serta jelas ketika dibaca.

Siswa dengan kemampuan sedang, berdasarkan analisis hasil tertulis pemecahan masalah mereka dan wawancara tentang bagaimana proses berikir konseptual, didapatkan data seperti pada tabel 3 . 


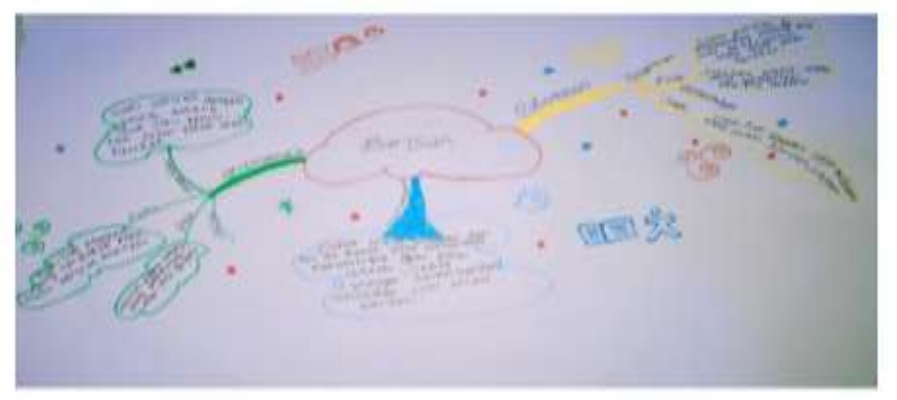

Gambar 1. Contoh Hasil Tertulis Siswa Kemampuan Tinggi

Tabel 3. Hasil Identifikasi Proses Berpikir Konseptual Melalui Mind Map Siswa Berkemampuan Sedang

\begin{tabular}{lccc}
\hline \multicolumn{1}{c}{ Indikator } & Tugas I & Tugas II \\
\hline $\begin{array}{l}\text { Membuat gambaran (image) dalam pikirannya tentang } \\
\text { ide yang akan dituangkan secara keseluruhan }\end{array}$ & $\sqrt{ }$ & $\sqrt{ }$ \\
\hline $\begin{array}{l}\text { Melakukan analisis untuk menemukan struktur inti } \\
\text { permasalahan }\end{array}$ & $\sqrt{ }$ & $\sqrt{ }$ \\
\hline Menemukan elemen kunci atau hubungan & $\sqrt{ }$ & $\sqrt{ }$ \\
\hline Membangun suatu strategi penyelesaian & $\sqrt{ }$ & $\sqrt{ }$ \\
\hline $\begin{array}{l}\text { Siswa mencapai tingkatan yang lebih tinggi pada } \\
\text { pemahaman permasalahan yang telah dihadapi. }\end{array}$ & $\sqrt{ }$ & $\sqrt{ }$ \\
\hline Menggunakan bahasa sendiri & - & $\sqrt{ }$ \\
\hline Menggunakan variasi warna (lebih dari 3) & $\sqrt{ }$ \\
\hline Tampilan menarik, jelas dan mudah dipahami & $\sqrt{ }$ & $\sqrt{ }$ \\
\hline Kelengkapan informasi yang disampaikan & - & - \\
\hline
\end{tabular}

Pada tabel 3 terlihat bahwa gambaran tentang proses berpikir konseptual siswa dengan kemampuan sedang menunjukkan bahwa subjek tersebut memenuhi ketujuh kriteria yang ada. Hampir mirip dengan siswa yang berkemampuan tinggi, siswa berkemampuan sedang juga membuat gambaran (image) terlebih dahulu dalam pikirannya sebelum menganalisis permasalahan untuk menemukan struktur inti dan elemen kunci agar dirinya dapat berpikir serta menemukan strategi pemecahan masalahnya. Siswa dengan kemampuan sedang juga mampu mencapai tingkatan yang lebih tinggi pada pemahaman tentang permasalahan yang dihadapinya. Tetapi sayangnya, pada hasil tertulis pengerjaan tugas siswa dengan kemampuan sedang, masih sama dengan siswa berkemampuan tinggi, penulis masih mendapati bahwa subjek belum mampu mengungkapkan ide/pemikirannya dengan menggunakan bahasa mereka sendiri dan subjek ini juga belum dapat mengungkapkan ide/informasi yang akan mereka sampaikan dengan lengkap. Siswa dengan kemampuan sedang masih menggunakan bahasa buku yang dituangkan pada mind map miliknya. Lain halnya tentang penggunaan variasi warna pada tampilan mind map, siswa pada kategori ini 
mampu memadu padankan warna (menggunakan lebih dari tiga warna) dan tidak berlebihan, tampilan mind map yang dihasilkan rapi, tetapi terkesan monoton dan kurang menarik serta tidak terlalu jelas ketika dibaca. Hal ini dikarenakan adanya kesalahan dalam memilih permainan warna, dimana siswa dengan kategori ini memadukan warna hijau tua sebagai baground/ dasar dari informasi yang dituliskan dengan warna hitam sehingga membuat tulisan tidak bisa dibaca dengan jelas.

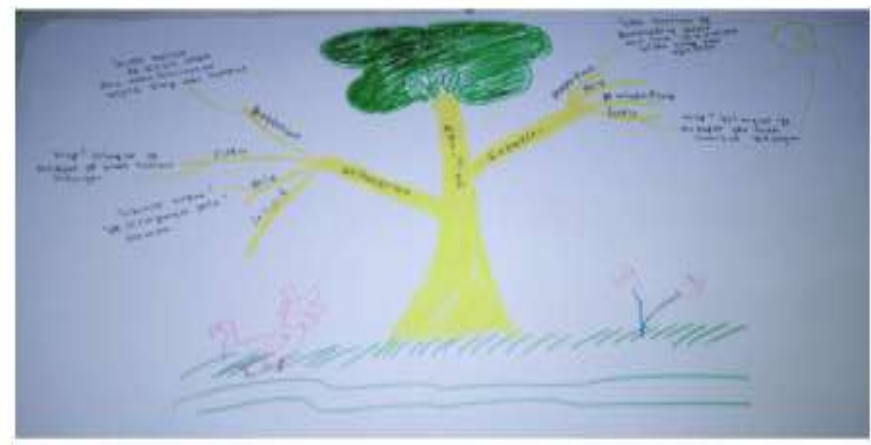

\section{Gambar 2. Contoh Hasil Tertulis Siswa Kemampuan Sedang}

Sedangkan untuk yang terakhir, hasil identifikasi proses berpikir konseptual terhadap hasil tugas tertulis dan wawancara yang telah dilakukan kepada siswa dengan kemampuan rendah menunjukkan data berikut:

Tabel 4. Hasil Identifikasi Proses Berpikir Konseptual Melalui Mind Map Siswa Berkemampuan Rendah

\begin{tabular}{lcc}
\hline \multicolumn{1}{c}{ Indikator } & Tugas I & Tugas II \\
\hline $\begin{array}{l}\text { Membuat gambaran (image) dalam pikirannya } \\
\text { tentang ide yang akan dituangkan secara } \\
\text { keseluruhan }\end{array}$ & $\sqrt{ }$ & $\sqrt{ }$ \\
\hline $\begin{array}{l}\text { Melakukan analisis untuk menemukan struktur } \\
\text { inti permasalahan }\end{array}$ & $\sqrt{ }$ & $\sqrt{ }$ \\
\hline Menemukan elemen kunci atau hubungan & $\sqrt{ }$ & $\sqrt{ }$ \\
\hline Membangun suatu strategi penyelesaian & $\sqrt{ }$ & $\sqrt{ }$ \\
\hline $\begin{array}{l}\text { Siswa mencapai tingkatan yang lebih tinggi pada } \\
\text { pemahaman permasalahan yang telah dihadapi. }\end{array}$ & - & - \\
\hline Menggunakan bahasa sendiri & - & - \\
\hline Menggunakan variasi warna (lebih dari 3) & $\sqrt{ }$ & $\sqrt{ }$ \\
\hline Tampilan menarik, jelas dan mudah dipahami & $\sqrt{ }$ & - \\
\hline Kelengkapan informasi yang disampaikan & - & $\sqrt{ }$ \\
\hline
\end{tabular}

Tabel 4 memperlihatkan bahwa proses berpikir konseptual siswa dengan kemampuan rendah menunjukkan bahwa subjek tersebut memenuhi keenam kriteria yang ada. Tidak terlalu berbeda dengan siswa yang berkemampuan tinggi dan sedang, siswa berkemampuan rendah ternyata 
juga membuat gambaran (image) terlebih dahulu dalam pikirannya sebelum menganalisis permasalahan untuk menemukan struktur inti atau elemen kunci agar dirinya dapat berpikir serta menemukan strategi pemecahan masalahnya. Perbedaan muncul ketika ternyata siswa dengan kemampuan rendah belum mampu mencapai tingkatan yang lebih tinggi pada pemahaman tentang permasalahan yang dihadapinya, mereka membuat peta konsep hanya untuk memenuhi tugas penyelesaian masalah. Selain itu pada hasil tertulis pengerjaan tugas siswa dengan kemampuan rendah, penulis juga masih mendapati bahwa subjek belum mampu mengungkapkan ide/pemikirannya menggunakan bahasa mereka sendiri dan terdapat beberapa informasi yang kurang lengkap sehingga memang pada gambaran mind map nya terlihat lebih sederhana jika dibandingkan dengan kedua kemampuan sebelumnya. Lain halnya tentang penggunaan variasi warna pada tampilan mind map, siswa pada kategori ini mampu memadu padankan banyak warna dengan penggunaan gradasi (menggunakan lebih banyak warna) dengan bagus dan terlihat lebih rapi dibanding siswa dengan kemampuan sedang. Pada siswa dengan kemampuan rendah, mereka tidak menuliskan pengertian/definisi dari masing-masing bagian. Hal ini merupakan perbedaan yang sangat terlihat jika dibandingkan dengan kedua subjek sebelumnya.

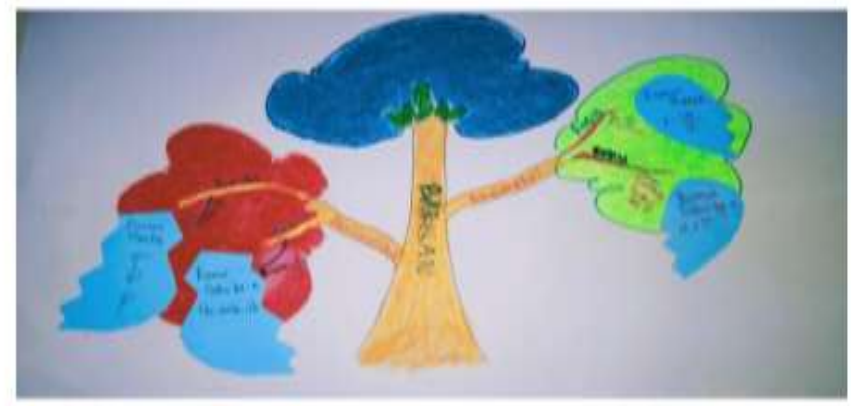

Gambar 3. Contoh Hasil Tertulis Siswa Kemampuan Rendah

Berdasarkan keseluruhan hasil pengerjaan tertulis subjek, peneliti dapat menarik sebuah pola yakni pada masing-masing mind map ketiga subjek telah memenuhi semua unsur-unsur pembentuk mind mapping antara lain tema besar yang digambarkan sebagai pokok pohon besar, sub tema yang digambarkan seperti cabang dan ranting dari pohon tersebut, urutan dan hubungan serta garis hirarki juga telah terlihat jelas seperti yang disampaikan oleh Swadarma (dalam Firdausi, 2020). Selain itu, ternyata mind map juga mampu meningkatkan pemahaman siswa terhadap suatu materi jika dibandingkan dengan membuat catatan biasa seperti yang diungkapkan oleh Hobri (2009) bahwa terdapat beberapa fungsi dari mind map, yaitu (1) fleksibel, (2) dapat memusatkan perhatian, (3) meningkatkan 
pemahaman dan (4) menyenangkan, imajinasi dan kreativitas siswa tidak terbatas sehingga akan membuat proses pembuatan dan peninjauan ulang catatan akan lebih menyenangkan. Hal sependapat juga diutarakan oleh Tapantoko (Faelasofi, 2016) bahwa mind map sangat baik digunakan oleh guru untuk meningkatkan daya hafal dan pemahaman siswa terhadap suatu materi serta meningkatkan kreativitasnya melalui kebebasan berekspresi yang diberikan.

Proses berpikir konseptual siswa secara keseluruhan dapat ditunjukkan melalui ketercapaian kelima indikator pertama yang telah diajukan peneliti. Pada subjek tinggi dan sedang, dari hasil analisis data diperoleh kesimpulan bahwa mereka mampu memenuhi semua kriteria yang diberikan, sedangkan untuk subjek dengan kemampuan rendah tidak mampu memenuhi indikator pencapaian tingkatan yang lebih tinggi pada pemahaman permasalahan yang telah dihadapi. Hasil analisis ini mendukung lebih lanjut pada pendapat yang dikemukakan oleh Nafi'an (2016) melalui publikasi penelitiannya yang menyatakan bahwa proses berpikir siswa dari kelompok atas cenderung berpikir konseptual dalam menyelesaikan soal cerita dan siswa dari kelompok tengah dalam menyelesaikan soal cerita pada materi pecahan cenderung pada proses berpikir semikonseptual. Sedangkan proses berpikir siswa dari kelompok bawah dalam menyelesaikan soal cerita pada materi pecahan cenderung pada proses berpikir komputasional.

\section{KESIMPULAN DAN SARAN}

Kemampuan penyelesaian masalah siswa sesungguhnya bisa diatasi dengan pemilihan metode belajar yang tepat yang akan diterapkan kepada siswa. Selain itu, memahami karakter proses berpikir konseptual siswa juga bisa menjadi satu hal yang penting untuk memilih kegiatan pembelajaran yang akan diberikan.

Siswa dengan kemampuan tinggi, dapat memenuhi 8 dari 9 indikator yang ada dengan mampu membuat gambaran (image) dalam pikirannya tentang ide yang akan dituangkan secara keseluruhan, melakukan analisis untuk menemukan struktur inti permasalahan, menemukan elemen kunci atau hubungan, membangun suatu strategi penyelesaian, mencapai tingkatan yang lebih tinggi pada pemahaman permasalahan yang telah dihadapi, banyak menggunakan variasi warna dengan tampilan yang menarik, jelas dan mudah dipahami serta memiliki kelengkapan informasi yang disampaikan. Untuk siswa dengan kemampuan sedang, mereka mampu memenuhi 7 dari 9 indikator yang diajukan yakni mampu membuat gambaran (image) dalam pikirannya tentang ide yang akan dituangkan secara keseluruhan, melakukan analisis untuk menemukan struktur inti permasalahan, menemukan elemen kunci atau hubungan, membangun suatu strategi penyelesaian, mencapai 
tingkatan yang lebih tinggi pada pemahaman permasalahan yang telah dihadapi, banyak menggunakan variasi warna dengan tampilan yang menarik, jelas dan mudah dipahami tapi informasi yang dsampaikan kurang jelas. Selain itu siswa berkemampuan sedang juga kurang mampu mengkombinasikan warna dengan baik. Selanjutnya pada siswa dengan kemampuan rendah hanya mampu memenuhi 6 dari 9 indikator yang ada, dengan tidak mampu mengungkapkan ide menggunakan bahasanya sendiri, kesulitan mencapai tingkatan yang lebih tinggi pada pemahaman permasalahan yang telah dihadapi serta kurangnya kelengkapan informasi yang diberikan. Tetapi dalam hal penggunaan warna, siswa dengan kemampuan rensah justru mampu menggunakan lebih banyak variasi warna dengan teknik gradasi.

Penelitian ini masih dapat dikembangkan dengan melakukan pemilihan variabel lain sebagai variabel penentu yang berhubungan langsung dengan proses berpikir konseptual dan metode pembelajaran mind mapping. Proses identifikasi proses berpikir konseptual siswa dengan menggunakan metode pemberian tugas membuat mind mapping juga dapat diaplikasikan selama proses pembelajaran berlangsung. Hal ini bisa dilakukan agar guru dapat mengukur peningkatan proses berpikir siswanya.

\section{DAFTAR RUJUKAN}

Choirudin, C. (2015). Efektivitas Pembelajaran Matematika dengan ELearning Berbasis Schoology. Universitas Terbuka.

Djamarah, S. B. (2008). Psikologi Belajar. Jakarta: PT. Rineka Cipta.

Faelasofi, R. (2016). Penerapan Metode Mind Mapping pada Pembelajaran Matematika. Jurnal E-DuMath, 2(2).

Firdausi, A. (2020). Peningkatan Prestasi Belajar Matematika dengan Model Pembelajaran Mind Mapping pada Siswa Kelas VIII SMP Negeri Terbuka 1 Gumukmas. IKIP PGRI Jember.

Hamda. (2020). Berpikir Konseptual dalam Pemecahan Masalah Matematika dan Implikasinya dalam Kehidupan Nyata. In Prosiding Seminar Nasional Universitas Cokroaminoto Palopo.

Hejny, M., Jirotkova, D., \& Kratochvilova, J. (2006). Early Conceptual Thinking. In Proceedings 30th Conference of the International Group for the Psychology of Mathematics Education (pp. 289-296). Prague: PME.

Hobri. (2009). Model-model Pembelajaran Inovatif. Jember: Center For Society Studies (CSS).

M., S. A. (2015). Efektivitas Pembelajaran PBL (Problem Based Learning) Terhadap Kemampuan Berpikir Kritis dan Kreatif Siswa Materi Tiga Dimensi. Universitas Terbuka.

Marpaung, Y. (1986). Proses Berpikir Siswa dalam Pembentukan Konsep 
Algoritma Matematis. In Makalah Pidato Dies Natalies XXXI IKIP Sanata Dharma Salatiga.

Masfingatin, T. (2014). Proses Berpikir Siswa Sekolah Menengah Pertama dalam Menyelesaikan Masalah Bangun Ruang Sisi Datar Berdasarkan Teori Van Hiele. JIPM (Jurnal Ilmiah Pendidikan Matematika), 3(1). https://doi.org/10.25273/jipm.v3i1.496

Maulidya, A. (2018). Berpikir dan Problem Solving. Berpikir Dan Problem Solving, 4.

Nafi'an, M. I. (2016). Analisis Berpikir Konseptual, Semikonseptual, dan Komputasinal Siswa SD dalam Menyelesaikan Soal Cerita. Jurnal Pendidikan Dan Pembelajaran Matematika (JP2M), 2(2).

Prasetyo. (2015). Identifikasi Proses Berpikir Siswa dalam Menyelesaikan Pernyataan pada Materi Biologi. Bioma, 4(1), 90-99.

Retna, M., Mubarokah, L., \& Suhartatik. (2013). Proses Berpikir Siswa dalam Menyelesaikan Soal Cerita ditinjau Berdasarkan Kemampuan Matematika. Jurnal Pendidikan Matematika STKIP PGRI Sidoarjo, 1(2), 71-82.

Skemp, R. R. (1987). The Psychology of Learning Mathematics. New Jersey: Lawrence Erlbaum associates, Inc.

Suparni. (2000). Proses Berpikir Siswa SLTP dalam Menyelesaikan Soal-Soal Operasi Hitung Pecahan Bentuk Aljabar. Universitas Negeri Surabaya.

Suryabrata, S. (2006). Psikologi Pendidikan. Jakarta: PT. Raja Grafindo Persada.

Susanto, H. B. (2011). Peningkatan Hasil Belajar IPA Dengan Menggunakan Teknik Mind Mapping (Peta Pikiran) Pada Materi Fungsi Alat Tubuh Manusi Siswa Kelas IV Semester Ganjil SDN Penataan Winongan Psuruan Tahun Ajaran 2011/2012. Universitas Jember.

Tony Buzan. (2008). Buku Pintar Mind Mapping. Gramedia Pustaka Umum. Wahyuniar, L. S., \& Widyawati, S. (2017). Proses Berpikir Mahasiswa Dalam Menyelesaikan Soal Kombinatorial Berdasarkan Kecerdasan Logis Matematis. NUMERICAL: Jurnal Matematika Dan Pendidikan Matematika. https://doi.org/10.25217/numerical.v1i2.177

Yanti, A. P., \& Syazali, M. (2016). Analisis Proses Berpikir Siswa dalam Memecahkan Masalah Matematika Berdasarkan Langkah-Langkah Bransford dan Stein ditinjau dari Adversity Quotien. Numer. J. Mat Dan Pendidik Mat, 1(1), 63-74.

Zubaidah, T. (2000). Proses Berpikir Keruangan Siswa Kls I SMP Negeri 32 Surabaya. Universitas Negeri Surabaya. 